\title{
Resistance of lettuce downy mildew's differential cultivars to root-knot nematodes
}

\author{
Roberta L. Vidal ${ }^{*}$, Renato S. Soares ${ }^{2}$, Bruna F. Kobayashi ${ }^{2}$, Carolina A. Franco ${ }^{2}$, Marcus V. Marin , \\ Pedro L.M. Soares ${ }^{2}$, Walter Maldonado-Junior², and Leila T. Braz ${ }^{2}$ \\ 'Escola Superior de Agricultura Luiz de Queiroz (ESALQ-USP), Avenida Pádua Dias, Piracicaba, São Paulo, 13418-900, Brasil. \\ "Corresponding author (robertalvidal@gmail.com). \\ "Universidade Estadual Paulista "Júlio de Mesquita Filho" (UNESP), Via de acesso Prof. Paulo Donato Castellane, Jaboticabal, São \\ Paulo, 14884-900, Brasil. \\ ${ }^{3}$ University of Florida, Gulf Coast Research \& Education Center (GCREC)/Institute of Food and Agricultural Sciences (IFAS), \\ Wimauma, Florida, USA.
}

Received: 8 August 2018; Accepted: 30 November 2018; doi:10.4067/S0718-58392019000200174

\begin{abstract}
Due to the harmful potential and existence of numerous races of lettuce downy mildew (Bremia lactucae Regel), several countries carry out the monitoring of these races through the use of differential cultivars of lettuce (Lactuca sativa $\mathrm{L}$.) The identification of resistance to other important diseases in these cultivars would be of great value for the lettuce's breeding, allowing the simultaneous selection for diseases. Among soil pathogens, the most important are the root-knot nematodes (Meloidogyne spp.) due their damage and difficulty of control. Thus, the present work evaluated the resistance of these differential cultivars (C-Set) against the two most important nematode species for the crop, M. javanica and M. incognita. The experiment was conducted in a completely randomized design, with eight replicates and initial population of 1000 eggs and juveniles. The evaluations were performed by the criteria of reproduction factor and reproduction index, $75 \mathrm{~d}$ after inoculation. Data were submitted to ANOVA and averages were compared by the Scott-Knott test ( $\mathrm{p}<0.05)$. All cultivars are considered susceptible to M. incognita by the reproduction factor, 'Argelès', 'Bedford', 'Design' and 'Grand Rapids' are considered as slightly resistant by the reproduction index. However, to M. javanica 'Argelès', 'Kibrille', 'Balesta', 'Colorado', 'Design', 'Bartoli', and 'NunDm15' are classified as resistant by the reproduction factor and very resistant by the reproduction index, and can be used as resistance source for simultaneous selection to downy mildew and this species of nematode.
\end{abstract}

Key words: Breeding, Bremia lactucae, Lactuca sativa, Meloidogyne spp., resistance genes.

\section{INTRODUCTION}

Lettuce (Lactuca sativa L.) is among the most popular vegetables worldwide. The oomycete Bremia lactucae Regel and the root-knot nematodes (Meloidogyne spp.) are noteworthy among the pathogens that have potential to affect its production.

Lettuce downy mildew is considered to be the main disease affecting the world-wide crop (Bauriegel et al., 2014; Parra et al., 2016). Due to its high genetic variability, B. lactucae presents several physiological races with different levels of pathogenicity, which hinders its control through genetic resistance. Given the importance of the disease in several countries, the International Bremia Evaluation Board (IBEB) was established in 1988, establishing and standardizing a race differentiation test for $B$. lactucae through the use of lettuce cultivars with different resistance genes to downy mildew. Sextet codes were established where each race of the pathogen would correspond to a coding, depending on their characteristics of virulence and behavior on the differential cultivars set (van Treuren et al., 2013). 
The identification and monitoring of the existing downy mildew races in each region are carried out by several countries in order to identify the genes that must be used as resistance source. Thus, because it is a material used in breeding programs in several countries, the identification of resistance within the differential cultivar's set to other important pathogens to the crop could also be explored, improving breeding programs selections.

Among the soil pathogens, root-knot nematodes stand out for their high harmful potential and difficulty of control. According to Ferreira et al. (2010), the use of cultural practices or nematicides are not always efficient due to the high intensity population and the wide range of hosts. In addition, the use of excess chemicals should be avoided whenever possible by the short cycle of the crop and its consumption in natura.

The species of the genus Meloidogyne are considered, among nematode species, the greatest cause of damage in crops worldwide (Jones et al., 2013; Saucet et al., 2016), leading to losses estimated at 10 billion euros per year (Jones et al., 2013). According to the authors, the popular name of this genus comes from the formation of galls in the root system of the infected plant, which correspond to giant cells with nourishment function of the nematode.

About 90 species belonging to this genus are reported (Perry et al., 2010), among which $M$. incognita (Kofoid and White) Chitwood, M. javanica (Treud) Chitwood, M. arenaria (Neal) Chitwood and M. hapla Chitwood have greater economic importance in the cultivation of vegetables. According to Zhang et al. (2010), lettuce plants infected by Meloidogyne spp. are less developed, yellowish, with small and often unmarketable heads, due to a weakened root system.

In addition to direct damage, roots damaged by nematodes become more prone to secondary fungal and bacterial infections, enhancing the damage to the crop (Mota et al., 2013).

Due to the importance of genetic resistance to the control of root-knot nematodes in the crop, the identification of resistance to them in materials already used as a source of downy mildew genes in several countries could bring great gains for lettuce breeding programs, allowing the simultaneous selection for both diseases. Therefore, the objective of this study was to evaluate the response of the current set of downy mildew differential cultivars, effective from 2016, C-set (IBEB, 2016), to M. incognita race 3 and M. javanica.

\section{MATERIALS AND METHODS}

The screening of the genotypes was carried out in a greenhouse. Obtaining the inoculum of Meloidogyne spp. and their identification were made in laboratory and the lettuce seedlings were produced in commercial nursery in 200-cell polyethylene trays, filled with substrate based on fiber from coconut husk and rice husk, and then covered with vermiculite.

Seventeen genotypes of Lactuca spp. (Green Towers, Odra, Dandie, R4T57D, UC Dm14, NunDm15, CG Dm16, Colorado, FrRsal-1, Argelès, RYZ 2164, RYZ 910457, Bedford, Balesta, Bartoli, Design, and Kibrille) belonging to the current downy mildew differential code C-Set (IBEB, 2016) were evaluated. The resistant 'Grand Rapids', susceptible 'Ariel', and the viability control of the inoculum, the tomato (Solanum lycopersicum L.) 'Santa Cruz Kada', were also evaluated.

The subpopulations of M. javanica and M. incognita race 3 were obtained from 'Santa Cruz Kada' tomato roots. The identification of the species was made based on the morphological features of the perineal pattern and labial region of the males, using a photonic microscope (Primo Star, Zeiss, Göttingen, Germany), and also based on the esterase isoenzymatic phenotype, using a vertical electrophoresis system (Mini Protean II, BIO-RAD, Hercules, California, USA).

The experiment was conducted in a completely randomized design, with eight replicates, plots composed of one plant, and arranged in a $2 \times 20$ factorial scheme, being two species of root-knot nematodes and 20 cultivars. The inoculation was carried out at the transplanting stage, when $5 \mathrm{~mL}$ nematode suspension were distributed in the seedling root system. The initial population (Ip) used was 1000 eggs and second stage juveniles (J2) per plot. The seedlings were transplanted into $1 \mathrm{~L}$ plastic pots, filled with a mixture of soil, sand and manure in the ratio $2: 3: 1$, pre-autoclaved $\left(120^{\circ} \mathrm{C}, 1 \mathrm{~atm}, 1 \mathrm{~h}\right)$.

Transplanting and inoculation occurred on 26 April 2017 for M. incognita and on 27 April 2017 for M.javanica and the evaluations of the experiments on 10 July 2017 and 11 July 2017, respectively, $75 \mathrm{~d}$ after transplanting and inoculation. In the evaluations, roots were processed according to the technique proposed by Hussey and Barker (1973) and the populations were estimated using the Peters counting chamber under a photonic microscope to obtain the total number of eggs and juveniles of second stage (TNEJ), which also consisted of the final population (Fp). 
The response of the cultivars to the infection by root-knot nematodes was evaluated using the Reproduction Factor (RF) and Reproduction Index (RI) criteria, taking into account also the statistical groupings of TNEJ. This way, within each statistical cluster, the treatment with the highest TNEJ value was used to define the RF and RI classes of all treatments belonging to that grouping, as specified below.

From the relation between final (Fp) and initial population (Ip), RF was determined according to the following formula:

$$
R F=F p / I p
$$

Based on the RF, genotypes were classified according to Oostenbrink (1966) in nematode resistant plants with RF $<1$, or in susceptible plants with $\mathrm{RF} \geq 1$.

The value of the reproduction index (RI) was calculated considering the susceptible control 'Ariel' as 100\% in relation to the reproduction of the nematodes obtained in lettuce genotypes. Thus, the following formula was used:

$$
R I \%=(F p \text { of the treatment } / F p \text { of 'Ariel') } 100
$$

Based on the reproduction index (RI\%) and according to the criterion established by Taylor (1967), the degree of resistance was classified as susceptible (S) when RI $>50 \%$ of the value obtained for the susceptible control; slightly resistant (SR) for RI with 26\%-50\%; moderately resistant (MoR) for RI with $11 \%-25 \%$; very resistant (VR) for RI with $1 \%-10 \%$; highly resistant (HR) for $\mathrm{RI}<1 \%$, and immune (I) for RI $=0$.

The data obtained from the variable TNEJ were transformed to $\log (x+5)$ to meet the normality assumptions and error distribution, however, in Tables 1 and 2 the original averages are presented in order to facilitate the interpretation. The data were submitted to ANOVA and the averages were compared by the Scott-Knott test $(\mathrm{p}<0.05)$ by the AgroEstat statistical software (Barbosa and Maldonado Júnior, 2015).

Table 1. ANOVA and comparison of means of the total number of eggs and juveniles of second stage (TNEJ) of 19 differential cultivars of lettuce (DC) and of the control of resistance, susceptibility and viability of the inoculum ${ }^{1}$.

\begin{tabular}{lc}
\hline DC and control & $\mathrm{TNE}^{\mathrm{I2}}$ \\
\hline Argelès & $3750 \mathrm{c}$ \\
CG Dm16 & $5250 \mathrm{c}$ \\
Kibrille & $5375 \mathrm{c}$ \\
Balesta & $9000 \mathrm{c}$ \\
UC Dm14 & $9375 \mathrm{~b}$ \\
Bedford & $400 \mathrm{c}$ \\
Odra & $6250 \mathrm{~b}$ \\
Colorado & $6375 \mathrm{c}$ \\
RYZ 2164 & $6750 \mathrm{~b}$ \\
Design & $2750 \mathrm{c}$ \\
RYZ 910457 & $10375 \mathrm{~b}$ \\
Dandie & $5500 \mathrm{~b}$ \\
R4T57 D & $7875 \mathrm{~b}$ \\
Bartoli & $10375 \mathrm{c}$ \\
FrRSal-1 & $14000 \mathrm{a}$ \\
NunDm15 & $4625 \mathrm{c}$ \\
Green Towers & $5875 \mathrm{c}$ \\
Ariel - C & $20375 \mathrm{a}$ \\
Grand Rapids $-\mathrm{C}$ & $1375 \mathrm{c}$ \\
Tomato 'Santa Cruz Kada' $-\mathrm{C}$ & $60750 \mathrm{a}$ \\
\hline Test F & $10.48^{* *}$ \\
\hline Nematodes (N) & \\
\hline Meloidogyne incognita race 3 & $14437.50 \mathrm{a}$ \\
\hline Meloidogyne javanica & $5562.50 \mathrm{~b}$ \\
\hline Test F & $201.36^{* *}$ \\
\hline Interaction (DC $\times$ N) & $6.77^{* *}$ \\
\hline CV, \% & 29.94 \\
\hline
\end{tabular}

${ }^{1}$ Means followed by the same letter in the column do not differ from each other by the Scott-Knott test $(\mathrm{p}<0.05)$.

${ }^{*},{ }^{* *}$ Significant at 0.05 and 0.01 probability levels, respectively. ns Nonsignificant.

${ }^{2}$ Original data of means transformed to $\log (x+5)$. 
Table 2. Unfolding of the interaction between the differential cultivar of lettuce downy mildew (C-Set) and two species of root-knot nematodes (Meloidogyne spp.) to the total number of eggs and second stage juveniles (TNEJ), reproduction factor (RF), reproduction index (RI) and response of materials (R).

\begin{tabular}{|c|c|c|c|c|c|c|c|c|c|c|c|}
\hline \multirow[b]{2}{*}{ Genotypes } & \multicolumn{5}{|c|}{ M. incognita race 3} & \multicolumn{5}{|c|}{ M. javanica } & \multirow[b]{2}{*}{ Test $\mathrm{F}$} \\
\hline & $\mathrm{TNEJ}^{5}$ & RF & $\mathrm{R}^{2,4}$ & RI & $\mathrm{R}^{3,4}$ & $\mathrm{TNEJ}^{5}$ & RF & $\mathrm{R}^{2,4}$ & RI & $\mathrm{R}^{3,4}$ & \\
\hline Argelès & $6750 \mathrm{bA}$ & 6.75 & $\mathrm{~S}$ & 27.55 & SR & $750 \mathrm{cB}$ & 0.75 & $\mathrm{R}$ & 4.61 & VR & $9.54^{* *}$ \\
\hline CG Dm16 & $8250 \mathrm{aA}$ & 8.25 & $\mathrm{~S}$ & 33.67 & $\mathrm{~S}$ & $2250 \mathrm{bB}$ & 2.25 & $\mathrm{~S}$ & 13.84 & SR & $5.15^{*}$ \\
\hline Kibrille & $10250 \mathrm{aA}$ & 10.25 & $S$ & 41.83 & $S$ & $500 \mathrm{cB}$ & 0.50 & $\mathrm{R}$ & 3.07 & VR & $40.64^{* *}$ \\
\hline Balesta & $18000 \mathrm{aA}$ & 18.00 & $\mathrm{~S}$ & 73.47 & $\mathrm{~S}$ & $0 \mathrm{cB}$ & 0.00 & $\mathrm{R}$ & 0.00 & VR & $57.15^{* *}$ \\
\hline UC Dm14 & $14750 \mathrm{aA}$ & 14.75 & $\mathrm{~S}$ & 60.20 & $\mathrm{~S}$ & $4000 \mathrm{bB}$ & 4.00 & $\mathrm{~S}$ & 24.61 & SR & $9.86^{* *}$ \\
\hline Bedford & $2500 \mathrm{bA}$ & 2.50 & $\mathrm{~S}$ & 10.20 & SR & $5500 \mathrm{bA}$ & 5.50 & $\mathrm{~S}$ & 33.84 & SR & $3.08^{\mathrm{ns}}$ \\
\hline Odra & $9000 \mathrm{aA}$ & 9.00 & $\mathrm{~S}$ & 36.73 & $\mathrm{~S}$ & $3500 \mathrm{bB}$ & 3.50 & $\mathrm{~S}$ & 21.54 & SR & $5.05^{*}$ \\
\hline Colorado & $12750 \mathrm{aA}$ & 12.75 & $\mathrm{~S}$ & 52.04 & $S$ & $0 \mathrm{cB}$ & 0.00 & $\mathrm{R}$ & 0.00 & VR & $53.60^{* *}$ \\
\hline RYZ 2164 & $8250 \mathrm{aA}$ & 8.25 & $\mathrm{~S}$ & 33.67 & $\mathrm{~S}$ & $5250 \mathrm{bA}$ & 5.25 & $\mathrm{~S}$ & 32.31 & SR & $1.64^{\mathrm{ns}}$ \\
\hline Design & $4750 \mathrm{bA}$ & 4.75 & $\mathrm{~S}$ & 19.38 & SR & $750 \mathrm{cB}$ & 0.75 & $\mathrm{R}$ & 4.61 & VR & $17.12^{* *}$ \\
\hline RYZ 910457 & $16250 \mathrm{aA}$ & 16.25 & $S$ & 66.32 & $\mathrm{~S}$ & $4500 \mathrm{bB}$ & 4.50 & $\mathrm{~S}$ & 27.69 & SR & $6.90^{* *}$ \\
\hline Dandie & 7750aA & 7.75 & $\mathrm{~S}$ & 31.63 & $S$ & $3250 \mathrm{bA}$ & 3.25 & $\mathrm{~S}$ & 20.00 & SR & $3.98^{*}$ \\
\hline R4T57 D & $13000 \mathrm{aA}$ & 13.00 & $\mathrm{~S}$ & 53.06 & S & $2750 \mathrm{bA}$ & 2.75 & $\mathrm{~S}$ & 16.92 & SR & $1.92^{\mathrm{ns}}$ \\
\hline Bartoli & $20750 \mathrm{aA}$ & 20.75 & $\mathrm{~S}$ & 84.69 & $S$ & $0 \mathrm{cB}$ & 0.00 & $\mathrm{R}$ & 0.00 & VR & $60.77^{* *}$ \\
\hline FrRSal-1 & $22000 \mathrm{aA}$ & 22.00 & $\mathrm{~S}$ & 89.79 & $\mathrm{~S}$ & $6000 \mathrm{aA}$ & 6.00 & $\mathrm{~S}$ & 36.92 & $\mathrm{~S}$ & $1.59^{\mathrm{ns}}$ \\
\hline NunDm15 & $8750 \mathrm{aA}$ & 8.75 & $\mathrm{~S}$ & 35.71 & $\mathrm{~S}$ & $500 \mathrm{cB}$ & 0.50 & $\mathrm{R}$ & 3.07 & VR & $23.21^{* *}$ \\
\hline Green Towers & $10500 \mathrm{aA}$ & 10.50 & $\mathrm{~S}$ & 42.85 & $\mathrm{~S}$ & $2250 \mathrm{bB}$ & 1.25 & $\mathrm{~S}$ & 7.69 & SR & $22.86^{* *}$ \\
\hline Ariel & $2450 \mathrm{aA}$ & 24.50 & $\mathrm{~S}$ & 100.00 & $\mathrm{~S}$ & $16250 \mathrm{aA}$ & 16.25 & $\mathrm{~S}$ & 100.00 & $\mathrm{~S}$ & $0.24^{\mathrm{ns}}$ \\
\hline Grand Rapids & $2250 \mathrm{bA}$ & 2.25 & $\mathrm{~S}$ & 9.18 & SR & $500 \mathrm{cB}$ & 0.50 & $\mathrm{R}$ & 3.07 & VR & $5.67^{*}$ \\
\hline Santa Cruz Kada & $67750 \mathrm{aA}$ & 67.75 & $\mathrm{~S}$ & 276.53 & $\mathrm{~S}$ & $53750 \mathrm{aA}$ & 53.75 & $\mathrm{~S}$ & 330.77 & $\mathrm{~S}$ & $0.07^{\mathrm{ns}}$ \\
\hline Teste F & $3.39^{* *}$ & & & & & $13.86^{* *}$ & & & & & \\
\hline
\end{tabular}

'Lower-case letters in the column and uppercase in the row do not differ by Scott-Knott test $(\mathrm{p}<0.05)$.

* ${ }^{* *}$ Significant at 0.05 and 0.01 probability levels, respectively. ${ }^{n}$ Nonsignificant.

${ }^{2} \mathrm{R}$ : Resistant, $\mathrm{RF}<1 ; \mathrm{S}$ : susceptible, $\mathrm{RF}>1$.

${ }^{3}$ S: Susceptible, RI > 51\%; SR: slightly resistant, $26 \%<$ RI < 50\%; MoR: moderately resistant, $11 \%<$ RI < 25\%; VR: very resistant, $1 \%<\mathrm{RI}<10 \%$; HR: highly resistant, $0<\mathrm{RI}<1 \%$; I: immune, RI $=0$.

${ }^{4}$ The classifications of the materials were corrected based on the statistical groupings of TNEJ, the treatment with higher value of TNEJ was considered for class definition within each grouping.

${ }^{5}$ Original data of means transformed to $\log (x+5)$.

\section{RESULTS AND DISCUSSION}

The environmental conditions were favorable to the development of the experiment, since they allowed the reproduction of the inoculum, which can be verified observing the high value of the total number of eggs and juveniles of second stage (TNEJ) of the viability control inoculum, the 'Santa Cruz Kada' tomato (Table 2). Also observed in Table 3 is the high value of the reproduction factor for both nematode species in tomato. The commercial 'Ariel' susceptible control also showed high values of TNEJ and FR.

There was significant interaction for the analyzed variable TNEJ by the $\mathrm{F}$ test at $1 \%$ probability (Table 2 ). Thus, the unfolding of the interaction was carry out for the two species of nematodes.

For most cultivars, higher TNEJ values were observed in M. incognita race 3 than $M$. javanica (Table 3), except for 'Bedford', 'RYZ 2164', 'Dandie', 'R4T57D', 'FrRSal-1', 'Ariel' and the tomato, which did not differ between the two species. However, this higher biotic potential of M. incognita in relation to M. javanica is not always observed in lettuce. Dias-Arieira et al. (2012) evaluated commercial lettuce cultivars and reported a greater reproduction of M. javanica for 'Vera', 'Isabela', 'Elisa', 'Elisabeth', and 'Salad Bowl'.

According to the reproduction factor (RF), all genotypes were considered susceptible to $M$. incognita race 3, with RF > 1 (Table 3). However, when considering only the TNEJ, 'Grand Rapids', 'Design', 'Bedford' and 'Argelès' were able to reduce the population of the nematode even if this is not reproduced by the FR. According to the work done by Gomes et al. (2000), crisp lettuce 'Grand Rapids' was evaluated as resistant to M. incognita, such divergences may be due to differences in methodology. The previously mentioned authors evaluated this cultivar in trays of expanded polystyrene, in addition to different initial populations and different evaluation criteria. 
When evaluated by the reproduction index (RI) and considering the highest TNEJ value of each statistical cluster for the definition of each class, 'Grand Rapids', 'Bedford', 'Design' and 'Argèles' were considered as slightly resistant and the remaining of the materials were considered susceptible, because they were in the same grouping of the tomato 'Santa Cruz Kada'.

For M. javanica, according to the FR (Table 3), 'Argelès', 'Kibrille', 'Balesta', 'Colorado', 'Design', 'Bartoli', 'NunDm15' and 'Grand Rapids' were classified as resistant.

Considering RI (Table 3), 'Balesta', 'Colorado', 'Bartoli', 'Argelès', 'Kibrille', 'Design', 'NunDm15' and 'Grand Rapids' were classified as very resistant to $M$. javanica; 'CGDm16', 'UCDm14', 'Bedford', 'RYZ 2164', 'RYZ 910457', 'Odra', 'Dandie', 'Green Towers' and 'R4T57D' as slightly resistant and 'FrRsal-1' and 'Santa Cruz Kada' tomato as susceptible.

In a study carried out by Dias-Arieira et al. (2012), the authors classified by RF a large part of the materials evaluated as resistant to M. incognita. These differences, as well as the author's own observations in relation to other studies, may be due to differences in the populations of nematodes used at work or in differences in the evaluation methodology. In this work the materials were evaluated with a larger initial population of $5000 \mathrm{eggs}$ and $\mathrm{J} 2$, and in a shorter evaluation time, $60 \mathrm{~d}$.

Khan and Ashraf (2006), evaluating the pathogenicity of $M$. incognita in lettuce, used different initial populations, varying between 250 and 8000 eggs and $\mathbf{J} 2$, and came to the result that with the increase of the initial population the RF decreased. In fact, an initial population larger than what the root is able to absorb at the beginning of its development can lead to an underestimated RF. There are no studies in the current literature that recommend the best number to compose the initial population in lettuce studies.

In relation to the evaluation criteria for genotype resistance, the RF proposed by Oostenbrink (1966), because it is based only on the initial and final amount of each material, becomes more restrictive in the classification of the resistance, and either the material allowed the reproduction of the nematode, being considered susceptible, or there was no reproduction of the nematode species, classifying the genotype as resistant. Thus, for selection of materials to be introduced in breeding programs, RF becomes more appropriate because it is more specific.

The RI proposed by Taylor (1967), because it is based on comparison with susceptible material, allows greater amplitude of classes (I, HR, VR, MoR, SR and S). Andrade-Júnior et al. (2016), using RI to evaluate sweet potato clones, concluded that it did not discern well the classification of the materials. However, the material used as a susceptible control was the 'Santa Clara' tomato, which is much more susceptible to the nematode and can easily overestimate the resistance of sweet potato cultivars. Therefore, RI becomes a more reliable index when used with a susceptible control of the same species and also to evaluate commercial materials that are already available to the producers, allowing to select those that allow less reproduction of the nematode.

In relation to the downy mildew resistance genes that each material has (Table 3) and its recommendation, 'NunDm 15 ' and 'Colorado' can be used in lettuce breeding programs in the Czech Republic, which has recommended the Dm15 and Dm18 genes to confer resistance to downy mildew (Table 1) (Petrzelová et al., 2013), for simultaneous selection to $M$. javanica. The Dm18 gene is also recommended to confer resistance to German downy mildew races (Lebeda and Zinkernagel, 2003). For Belgium, 'NunDm15' may also be exploited for resistance to downy mildew (Van Hese et al., 2016). In Brazil, in a study made by Nunes et al. (2016), it is recommended to use the Dml8 and FR-38, conferred by the differentiating 'Colorado' and 'Argelès'.

'Argelès', 'Kibrille', 'Balesta', 'Colorado', 'Design', 'Bartoli' and 'NunDm15' can be used as source of resistance in lettuce breeding programs to confer resistance to M. javanica and lettuce mildew. However, inheritance studies of $M$. javanica resistance of these materials should be performed in order to guide selection in breeding programs.

Despite the importance of genetic resistance as one of the main pillars in the integrated management of nematodes, it is important to emphasize that the use of resistant materials alone is not a guarantee of success in the control of this phytopathogen, since new races can emerge and outbreak the resistance. Therefore, the control of the phytonematodes must always be done in an integrated way, using several measures that aim to reduce its population to low levels. 
Table 3. Set of 'C-Set' differentiators and their genes/resistance factor to lettuce downy mildew'

\begin{tabular}{lc}
\hline Differential cultivars & Gene/resistance genes \\
\hline Green Towers & - \\
Odra $^{2}$ & - \\
Dandie & Dm3 \\
R4T57 D & Dm4 \\
UC Dm14 & Dm14 \\
NunDm15 & Dm15 \\
CG Dm16 & Dm16 \\
Colorado & Dm18 \\
FrRSal-1 & R 36 + R 37 \\
Argelès & R 38 \\
RYZ 2164 & "Silvinas" \\
RYZ 910457 & "Murai" \\
Bedford & Monogenic \\
Balesta & Monogenic \\
Bartoli & Monogenic \\
Design & - \\
Kibrille $^{3}$ & - \\
\hline
\end{tabular}

${ }^{1}$ Adapted from IBEB (2016).

${ }^{2}$ Do not have genes/resistance factors.

${ }^{3}$ Mechanism of resistance not yet reported.

\section{CONCLUSIONS}

All cultivars are susceptible to Meloidogyne incognita race 3 by the reproduction factor, 'Grand Rapids', 'Design', 'Bedford' and 'Argèles' are slightly resistant to this species by the reproduction index.

'Argelès', 'Kibrille', 'Balesta', 'Colorado', 'Design', 'Bartoli' and 'NunDm15' are resistant to M. javanica by the reproduction factor and can be exploited in simultaneous selection for downy mildew and this species of nematode.

\section{ACKNOWLEDGEMENTS}

This work was supported by Universidade Estadual Paulista "Júlio de Mesquita Filho" - Câmpus de Jaboticabal and Coordenação de Aperfeiçoamento de Pessoal de Nível Superior (CAPES), Brasil.

\section{REFERENCES}

Andrade-Júnior, V.C., Gomes, J.A.A., Oliveira, C.M., Azevedo, A.M., Fernandes, J.S.C., Gomes, L.A.A., et al. 2016. Resistência de clones de batata-doce a Meloidogyne javanica. Horticultura Brasileira 34:130-136. doi:10.1590/S0102-053620160000100020.

Barbosa, J.C., e Maldonado Júnior, W. 2015. Experimentação agronômica \& AgroEstat: Sistema para análises estatísticas de ensaios agronômicos. Fundação de Apoio a Pesquisa, Ensino e Extensão (FUNEP), Jaboticabal, Brasil.

Bauriegel, E., Brabandt, H., Garber, U., and Herppich, W.B. 2014. Chlorophyll fluorescence imaging to facilitate breeding of Bremia lactucae-resistant lettuce cultivars. Computers and Electronics in Agriculture 105:74-82. doi10.1016/j.compag.2014.04.010.

Dias-Arieira, C.R., Cunha, T.P.L., Chiamolera, F.M., Puerari, H.H.F., Biela, F., and Santana, S.M. 2012. Reaction of vegetables and aromatic plants to Meloidogyne javanica and M. incognita. Horticultura Brasileira 30:322-326. doi:10.1590/S0102-05362012000200023.

Ferreira, S., Gomes, L.A.A., Maluf, W.R., Campos, V.P., Carvalho Filho, J.L.S., and Santos, D.C. 2010. Resistance of dry bean and snap bean cultivars to root-knot nematodes. HortScience 45:320-322.

Gomes, L.A.A., Maluf, W.R., and Campos, V.P. 2000. Inheritance of the resistant reaction of the lettuce cultivar 'Grand Rapids' to the southern root-knot nematode Meloidogyne incognita (Kofoid and White) Chitwood. Euphytica 114:37-46. doi:10.1023/A:1003991819523.

Hussey, R.S., and Barker, K.R. 1973. A comparison of methods of collecting inocula of Meloidogyne spp., including a new technique. Plant Disease Reporter 57:1025-1028. 
IBEB. 2016. The International Bremia Evaluation Board (IBEB) aims to identify new races of Bremia lactucae that pose a significant threat to the European lettuce industry. International Seed Federation, Nyon, Switzerland. Available at http://www.worldseed.org/our-work/plant-health/other-initiatives/ibeb/ (accessed June 2018).

Jones, J.T., Hargeman, A., Danchin, E.J., Gaur, H.S., Helder, J., Jones, M.G.K., et al. 2013. Top 10 plant-parasitic nematodes in molecular plant pathology. Molecular Plant Pathology 14:946-961. doi:10.1111/mpp.12057.

Khan, T.A., and Ashraf, M.S. 2006. Pathogenicity and life cycle of Meloidogyne incognita and M. Javanica on lettuce (Lactuca sativa L.) Pakistan Journal of Nematology 24:163-169.

Lebeda, A., and Zinkernagel, V. 2003. Evolution and distribution of virulence in the German population of Bremia lactucae. Plant Pathology 52:41-51. doi:10.1046/j.1365-3059.2003.00802.

Mota, F.C., Alves, G.C.S., Giband, M., Gomes, A.C.M.M., Sousa, F.R., Mattos, V.S., et al. 2013. New sources of resistance to Meloidogyne incognita race 3 in wild cotton accessions and histological characterization of the defense mechanisms. Plant Pathology 62:1173-1183. doi:10.1111/ppa.12022.

Nunes, R.C., Castoldi, R., Gomes, R.F., Tobar-Tosse, D.E., e Braz, L.T. 2016. Levantamento de raças do agente causador do míldio da alface no Estado de São Paulo em 2012 e 2013. Summa Phytopathologica 42:53-58. doi:10.1590/0100-5405/2057.

Oostenbrink, M. 1966. Major characteristics of the relation between nematodes and plants. Mededelingen van de Landbouwhogeschool te Wageningen 66:1-46.

Parra, L., Maisonneuve, B., Lebeda, A., Schut, J., Christopoulo, M., Jeuken, M., et al. 2016. Rationalization of genes for resistance to Bremia lactucae in lettuce. Euphytica 210:309-326. doi:10.1007/s10681-016-1687-1.

Perry, R.N., Moens, M., and Starr, J.L. 2010. Root-knot nematodes. CABI, Wallingford, England.

Petrzelová, I., Lebada, A., and Kosman, E. 2013. Distribution, disease level and virulence variation of Bremia lactucae on Lactuca sativa in the Czech Republic in the period 1999-2011. Journal of Phytopathology 161:503514. doi:10.1111/jph.12098.

Saucet, S.B., Ghelder, C.V., Abad, P., Ducal, H., and Esmenjaud, D. 2016. Resistance to root-knot nematodes Meloidogyne spp. in woody plants. New Phytologist 211:41-56. doi:10.1111/nph.13933.

Taylor, A.L. 1967. Introduction to research on plant nematology: an FAO guide to the study and control of the plant-parasitic nematodes. Food and Agricultural Organization of the United Nations, Rome, Italy.

Van Hese, N., Huang, C.J., Vleesschauwer, D., Delaere, I., Pauwelyn, E., Bleyaert, P., et al. 2016. Evolution and distribution of virulence characteristics of Belgian Bremia lactucae populations between 2008 and 2013. European Journal of Plant Pathology 144:431-441. doi:10.1007/s10658-015-0779-4.

van Treuren, R., Van Der Arend,A.J.M., and Schut, J.W. 2013. Distribution of downy mildew (Bremia lactucae Regel) resistances in a genebank collection of lettuce and its wild relatives. Plant Genetic Resources: Characterization and Utilization 11:15-25. doi:10.1017/S1479262111000761.

Zhang, L., Zhang, Y., Chen, R., Zhang, J., Wang, T., Li, H. et al. 2010. Ectopic expression of the tomato Mi-1 gene confers resistance to root knot nematodes in lettuce (Lactuca sativa). Plant Molecular Biology Reporter 28:204-211. doi:10.1007/s11105-009-0143-y. 